\title{
Inhibition by diethylstilboestrol of proliferative potential of follicles of different sizes in immature rat ovaries
}

\author{
A. Chakravorty, V. B. Mahesh and T. M. Mills \\ Department of Physiology \& Endocrinology, Medical College of Georgia, Augusta, GA 30912, USA
}

\begin{abstract}
Summary. Intact immature female rats were treated with 1, 2, 3 or 4 subcutaneous injections of $2 \mathrm{mg}$ diethylstilboestrol (DES)/rat at intervals of $24 \mathrm{~h}$ and then killed. Ovaries were collected, cleaned, enzymically digested and serially filtered through Teflon sieves to yield follicles of diameter $<200 \mu \mathrm{m}$ (small), 200-400 $\mu \mathrm{m}$ (medium) and $>400 \mu \mathrm{m}$ (large). Follicular supernatant was collected and granulosa cells were extracted from these isolated follicles. There was a general increase in $\left[{ }^{3} \mathrm{H}\right]$ thymidine incorporation in all sizes of follicles after 1 or 2 DES injections, the increase in the medium and large follicles being significant after 2 doses. With 3 and 4 injections of DES, there was a sudden decrease in the rates of $\left[{ }^{3} \mathrm{H}\right]$ thymidine incorporation, particularly in the medium-sized follicles, which also had higher concentrations of follicular supernatant protein. Protein contents in small and large follicles did not change significantly. The follicular supernatant protein had a specific and dose-dependent inhibitory effect on $\left[{ }^{3} \mathrm{H}\right]$ thymidine incorporation when added to cultures of rapidly dividing granulosa cells. Addition of the same amounts of bovine serum albumin (BSA) to the cultures had no effect. Heat-denaturing did not abolish the inhibition by the protein. Removal of the protein from the cultures after the first $48 \mathrm{~h}$ resulted in a rebound increase in $\left[{ }^{3} \mathrm{H}\right]$ thymidine incorporation during the following $48 \mathrm{~h}$, showing that the inhibitory effects were reversible. Though aromatase activity after 1 or 2 DES injections abruptly decreased after 3 and 4 injections, follicular supernatant protein had no effect on steroidogenesis in cultured granulosa cells.

Taken together, these findings suggest that oestrogen can inhibit follicular development, depending on the duration of exposure. We propose that the inhibitory effects of DES on cell proliferation are mediated via the synthesis of a specific peptide factor which is produced in high amounts in the medium-sized follicles only, on prolonged exposure to the oestrogen. This factor may be autocrine or paracrine, serving as an in-built autoregulatory control mechanism for follicle development, particularly at pro-oestrus, when oestrogen concentations are highest.
\end{abstract}

Keywords: diethylstilboestrol; follicle; thymidine; protein; inhibition; rat

\section{Introduction}

Under physiological conditions, oestrogen is a major endocrine secretion of the preovulatory follicle and exists in follicular fluid in very high concentrations. Hence, it is believed to fulfil a multitude of roles in co-ordinating follicle development by acting locally in an autocrine or paracrine manner. Oestrogen has been considered mitogenic, but recent evidence shows that oestrogens can inhibit as well as stimulate cell division. The predominant function depends upon species, dose and duration of exposure (Soto \& Sonnenschein, 1987; Hutz, 1989). The present study tested the hypothesis that prolonged and excessive exposure to oestrogen is detrimental to follicular development because of its paracrine effects on proliferation and differentiation of granulosa cells 
from follicles of specific sizes. A reduced responsiveness to gonadotrophins in diethylstilboestroltreated granulosa cells has been shown (Chakravorty et al., 1990). We hypothesize that the inhibition of proliferation is mediated via the synthesis of a peptide factor, but that differentiation processes (aromatase) are inhibited by a different mechanism. This hypothesis was tested by determining the incorporation of $\left[{ }^{3} \mathrm{H}\right]$ thymidine into cellular DNA as a measure of proliferative potential in a short- or long-term cell culture. Since ovarian follicular fluid constitutes the physiological milieu of granulosa cells, the effects of proteins (in follicular supernatant fluid from different-sized follicles) on thymidine incorporation was also studied.

\section{Materials and Methods}

Animals. Intact, immature female Sprague-Dawley rats were obtained from Holtzman Laboratories (Madison, WI, USA). The animals were housed in temperature-controlled $\left(22^{\circ} \mathrm{C}\right)$ quarters with $14 \mathrm{~h}$ light and $10 \mathrm{~h}$ darkness and provided with commercial rat chow and water ad libitum.

Experimental protocol. The animals were divided into four groups for four regimens of treatments with $2 \mathrm{mg}$ of diethylstilboestrol (DES, Steraloids Inc., Wilton, NH, USA) subcutaneously in $0.2 \mathrm{ml}$ of propylene glycol. All animals were killed by decapitation at 28 days of age. The treatment groups were according to the number of DES injections given at times prior to sacrificing (indicated in parentheses): $1(24 \mathrm{~h}), 2(48 \mathrm{~h}), 3(72 \mathrm{~h})$ and $4(96 \mathrm{~h})$. The ovaries were removed and cleaned of fat, follicles were isolated and separated by size and then granulosa cells were extracted from follicles of three sizes as described by Chakravorty et al. (1990). With these granulosa cells, $\left[{ }^{3} \mathrm{H}\right]$ thymidine incorporation and aromatase activity were measured as described previously. Follicular supernatant fluid was collected after separation of the granulosa cells by centrifugation at $50 \mathrm{~g}$ for $5 \mathrm{~min}$ and its protein content was measured (Lowry et al., 1951).

Cell culture for effects of follicular-fluid proteins. The granulosa cell culture system was a modification of the system of Daniel \& Armstrong (1980). Briefly, $1.25 \times 10^{5}$ viable granulosa cells from medium-sized follicles, collected after 2 injections of DES, were plated in 22.6-mm wells containing McCoy`s $5 \mathrm{~A}$ buffer with Hepes and L-glutamine and $1 \%$ foetal calf serum (Gibco, treated with charcoal to remove steroids). These cells, chosen for high mitotic activity, were incubated without (control) or with follicular supernatant protein in duplicates, or with $150 \mu \mathrm{g}$ of bovine serum albumin (BSA; to rule out nonspecific protein effects). The different doses of total follicular supernatant protein (collected after 1,2,3 and 4 injections of diethylstilboestrol) added to the cells in culture were as follows: $150 \mu \mathrm{g}$ (Fig. 4a) and $300 \mu \mathrm{g}$ (Fig. 4b) of intact protein from small, medium and large follicles. The effects of $300 \mu \mathrm{g}$ of heated ( $85 \mathrm{C}, 10 \mathrm{~min}$ ) follicular supernatant protein from only the medium follicles was also investigated (Fig. $4 \mathrm{~b}$ ). The cells were incubated for $36 \mathrm{~h}$, then $0.5 \mu \mathrm{Ci}$ [methyl- ${ }^{3} \mathrm{H}$ ]thymidine (ICN Radiochemicals, Irvine, CA, USA; sp. act $37 \mathrm{Ci} / \mathrm{mmol} ; 0.5 \mu \mathrm{Ci} / \mathrm{ml}$ ) was added to each well and the culture continued for an additional $12 \mathrm{~h}$. The cells were then washed three times with ice-cold buffer (containing a 100 -fold excess unlabelled thymidine) to remove excess radiolabelled thymidine and dispersed with $0 \cdot 1 \mathrm{M}-\mathrm{KOH}$ with $1 \%$ triton. The DNA was precipitated with trichloroacetic acid (Fisher Scientific, $10 \% \mathrm{w} / \mathrm{v}$ ) and the radioactivity of the pellet was measured.

Reversibility of the effects of follicular supernatant proteins was tested by culturing two sets of granulosa cells for $48 \mathrm{~h}$ with $300 \mu \mathrm{g}$ of follicular supernatant protein (collected from the medium follicles after 4 diethylstilboestrol injections). In the second set, the protein was removed, and the cells were washed and then cultured in media alone for an additional $48 \mathrm{~h}$. The incorporation of $\left[{ }^{3} \mathrm{H}\right]$ thymidine was tested during the last $12 \mathrm{~h}$ of culture in each set.

Radioimmunoassays. Progesterone and oestradiol concentrations were assayed using the progesterone antibody MCG D3 (Mills \& Osteen, 1977) and the oestradiol antibody TGE 2 K (Parker et al., 1975). Standard curve ranged from 5 to $1000 \mathrm{pg} /$ tube with $40-50 \%$ binding. Intra- and interassay variations were $6 \cdot 3$ and $8 \cdot 3 \%$, respectively for oestrogen and 7.7 and $9.6 \%$, respectively, for progesterone.

Statistical analysis. Results were analysed by one-way analysis of variance (ANOVA) and Tukey's multiple range test using the STATGRAPHICS statistical programme (Statistical Graphics Corporation, STSC, Inc., USA).

\section{Results}

\section{Short-term thymidine incorporation after different doses of diethylstilboestrol}

Incorporation rates did not change significantly in granulosa cells from the small and large follicles with increasing diethylstilboestrol treatment (Fig. 1), but marked changes were seen in the cells from the medium follicles. Two injections of diethylstilboestrol significantly increased 


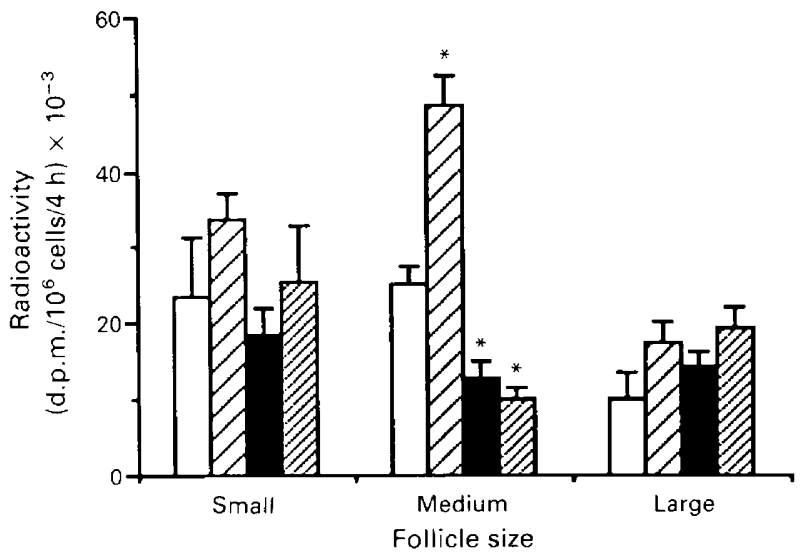

Fig. 1. $\left[{ }^{3} \mathrm{H}\right]$ thymidine incorporation in granulosa cells from follicles of three sizes after one $(\square)$, $2(\mathbb{Z}), 3(\boldsymbol{\square})$ or $4(\mathbb{Z})$ injections of diethylstilboestrol $(2 \mathrm{mg} / \mathrm{rat})$. Data are means \pm s.e.m. from 5 experiments, each with pooled ovaries from 10-12 animals. Values within each follicle size were compared between treatments; differences were significant only in the medium follicles $\left({ }^{*} P<0.01\right)$.

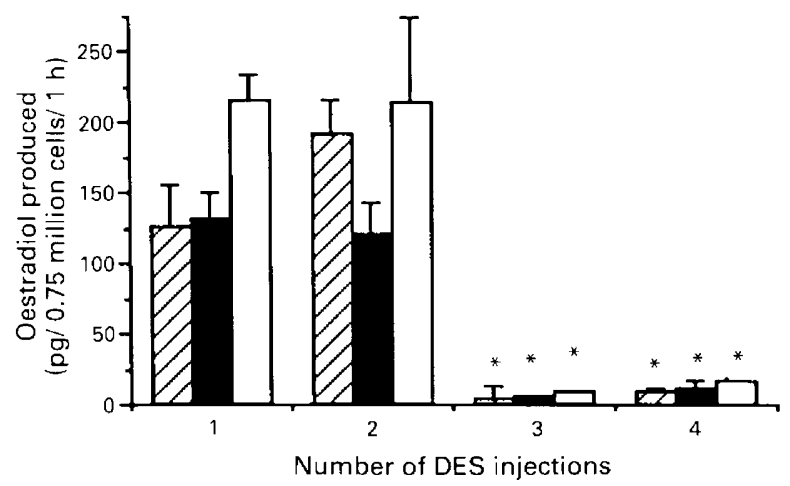

Fig. 2. Aromatase activity in rat granulosa cells of small $(\mathbb{\square})$, medium ( $\square$ ) and large $(\square)$ follicles after 1, 2, 3 or 4 doses of $2 \mathrm{mg}$ of diethylstilboestrol (DES)/rat. Data are means \pm s.c.m. from 5 experiments, each with pooled ovaries from 10-12 animals. Values for all follicle sizes after 3 and 4 DES injections were significantly different $\left({ }^{*}\right)$ from those after 1 or 2 injections $(P<0.01)$.

thymidine incorporation, but this effect was not evident after 3 and 4 injections and rates were significantly lower than after 1 or 2 doses.

\section{Aromatase activity}

Analysis of the capacity of the granulosa cells for oestrogen synthesis after different doses of diethylstilboestrol (Fig. 2) showed aromatase activity in granulosa cells after 1 or 2 injections, but activity was significantly inhibited after 3 and 4 injections. The inhibition was seen in follicles of all sizes. 


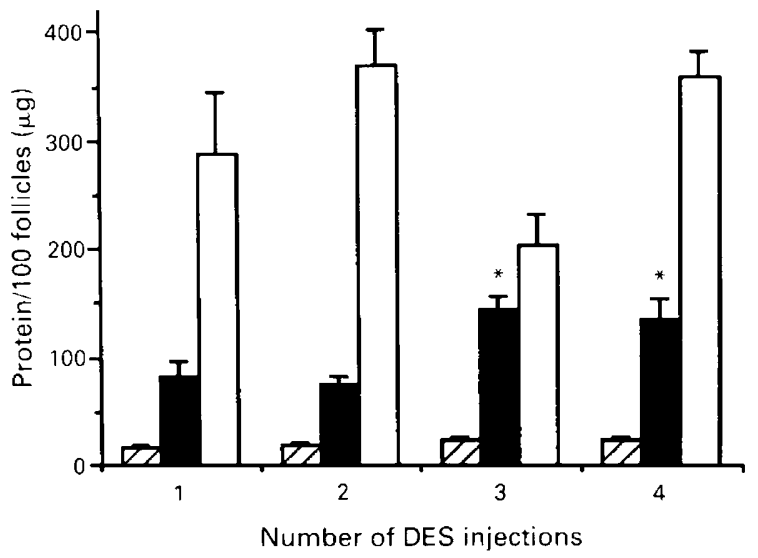

Fig. 3. Protein content of small $(\mathbb{C})$, medium $(\square)$ and large $(\square)$ follicles after $1,2,3$ or 4 diethylstilboestrol (DES; $2 \mathrm{mg} / \mathrm{rat}$ ) injections. Data are means \pm s.e.m. from 5 experiments, each with pooled ovaries from 10-12 animals. Significant differences were seen only in the medium-sized follicles $\left({ }^{*} P<0 \cdot 01\right)$.

\section{Protein content of follicular supernantant}

Results were statistically analysed by ANOVA, comparing between-treatment regimens within each follicle size (Fig. 3). Protein content of follicular supernatant increased significantly with increasing treatment with diethylstilboestrol in medium, but not in large or small, follicles.

\section{Effects of follicular supernatant protein on thymidine incorporation}

Follicular supernatant containing $150 \mu \mathrm{g}$ protein from the small follicles did not have any significant effect (Fig. 4a), but that from the large follicles stimulated incorporation after 2 doses of diethylstilboestrol; $150 \mu \mathrm{g}$ of follicular protein from the medium follicles significantly inhibited incorporation after 3 and 4 diethylstilboestrol injections. When $300 \mu \mathrm{g}$ of the protein was tested (Fig. 4b), follicular supernatant from the large follicles after 2 injections also stimulated incorporation, but that from the small follicles inhibited incorporation after 2,3 and 4 injections; $300 \mu \mathrm{g}$ follicular protein from the medium follicles inhibited the rates of incorporation even more, showing a dose-dependent effect. Heated follicular supernatant from the medium follicles inhibited thymidine incorporation after 2, 3 and 4 diethylstilboestrol injections.

Follicular fluid containing $300 \mu \mathrm{g}$ protein from medium follicles collected after 4 diethylstilboestrol injections inhibited incorporation significantly during the first $48 \mathrm{~h}$ of culture, but, when the protein was removed and cells were washed, rates of incorporation were greater than in control during the following $48 \mathrm{~h}$ of culture (Fig. 5).

\section{Effects of follicular supernatant on steroidogenesis}

When granulosa cells were cultured with or without $300 \mu \mathrm{g}$ of follicular supernatant protein and media were collected and assayed for oestrogen and progesterone concentration, there was no inhibition of steroidogenesis (Fig. 6). On the contrary, there was stimulation of both oestrogen and progesterone production, possibly due to other factors and a ready supply of substrates.

\section{Numbers of granulosa cells and follicles}

Numbers of small and medium follicles increased, but numbers of large follicles decreased with increasing duration of exposure to diethylstilboestrol (Table 1). The number of granulosa cells 


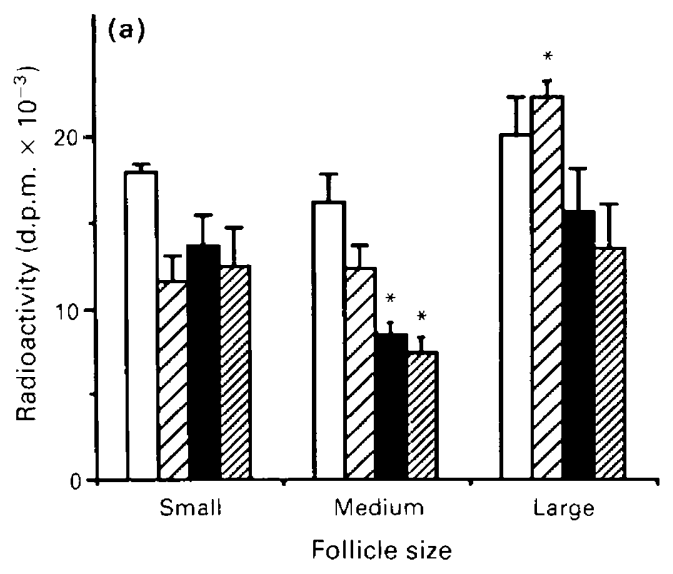

(a)

(b)

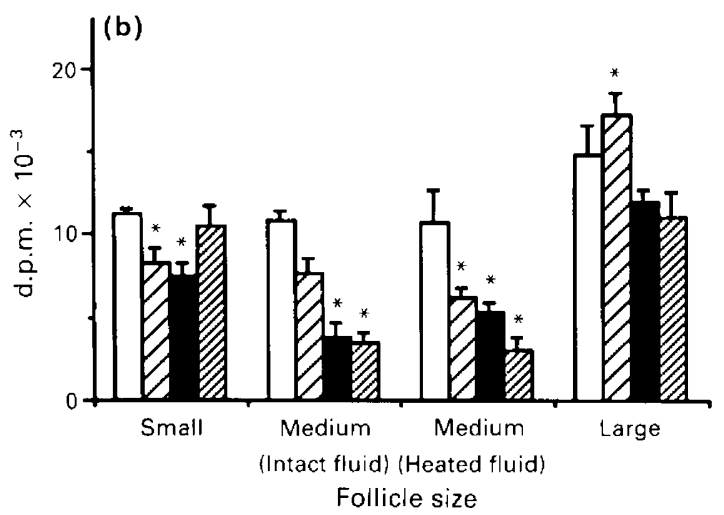

Fig. 4. Effects of (a) $150 \mu \mathrm{g}$ of bovine serum albumin (BSA) and $150 \mu \mathrm{g}$ of intact follicular supernatant protein and (b) $300 \mu \mathrm{g}$ of intact follicular supernatant protein from small, medium and large follicles and also $300 \mu \mathrm{g}$ of heated follicular supernatant protein from only medium follicles on $\left[{ }^{3} \mathrm{H}\right]$ thymidine incorporation into rat granulosa cell DNA in culture for $48 \mathrm{~h}$ after

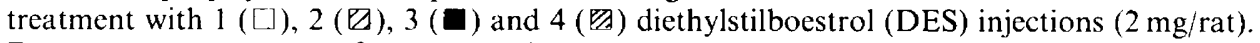
Data are means \pm s.e.m. from 5 experiments, each with pooled ovaries from 10-12 animals. Control \pm s.e.m. (incorporation rates in the absence of follicular protein) values were $12.4 \pm 0 \cdot 6$ d.p.m. and incorporation rates with $150 \mu \mathrm{g}$ of BSA were $12 \cdot 9 \pm 0.8$ d.p.m.; *values significantly different from control $(P<0.01)$.

expressed per follicle-size per ovary declined in the medium follicles, and decreased significantly with increasing diethylstilboestrol exposure. A significant increase was seen in the number of granulosa cells in the large follicles after 2 and 3 injections, while that in the small follicles increased after 3 and 4 injections of diethylstilboestrol.

\section{Discussion}

The process of follicular growth and maturation is complex and is regulated by many factors, which are stage-specific (Hirshfield \& Schmidt, 1987). The most important controllers of follicle development are follicle-stimulating hormone (FSH) and luteinizing hormone ( $\mathrm{LH}$ ) from the pituitary and the ovarian steroid oestradiol produced by the granulosa cells. Although all follicles 


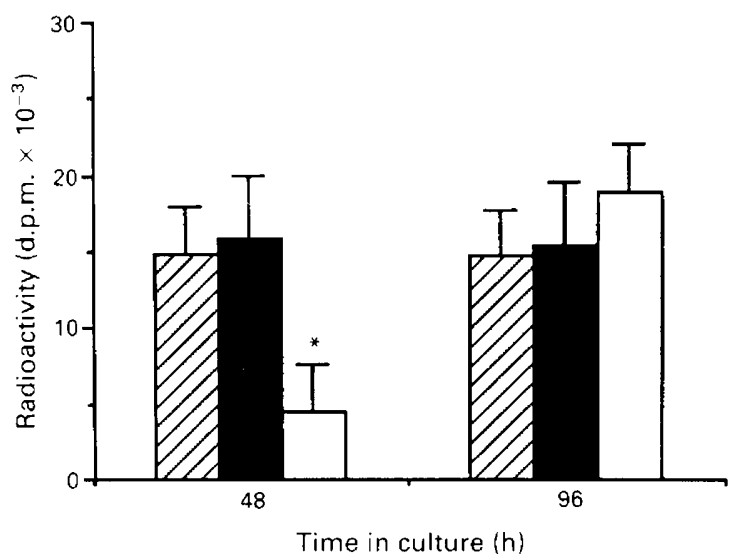

Fig. 5. Reversibility of the inhibitory effects of follicular supernatant protein from medium follicles (from diethylstilboestrol-treated rats) on $\left[{ }^{3} \mathrm{H}\right]$ thymidine incorporation into rat granulosa cell DNA in culture. Cells were cultured with buffer $(\mathbb{Z})$, bovine serum albumin, BSA (ם) or $300 \mu \mathrm{g}$ of follicular supernatant protein $(\square)$. Data are means \pm s.e.m. from 3 experiments, each with pooled ovaries from $10-12$ animals; *significantly different values $(P<0.01)$.

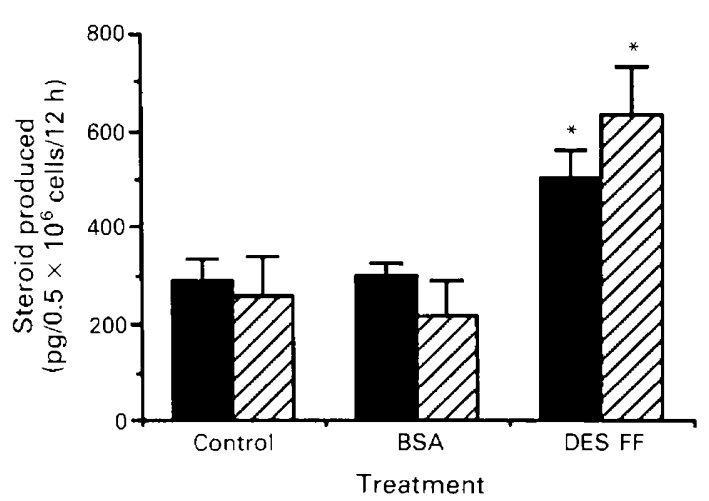

Fig. 6. Effects of $300 \mu \mathrm{g}$ of follicular supernatant protein (DES-FF) and bovine serum albumin (BSA) on oestrogen ( $\mathbf{Q})$ and progesterone $(\mathbb{0})$ production by rat granulosa cells in culture. Data represents means \pm s.e.m. from 3 experiments, each with duplicate wells; *significantly different values between treatment groups $(P<0.05)$.

are apparently exposed to the same fluctuations in these hormones, not all are equally responsive; some ovulate and others become atretic, indicating the presence of intragonadal regulatory factors which modulate the effects of these major hormones. The sources of these intragonadal factors are the follicular components and these factors are present in high amounts in the follicular fluid. Several growth factors are produced by the ovary and they are fine-tune modulators of gonadotrophin effects (Dorrington et al., 1988). Some of these factors could be important in determining the sequence of proliferation and differentiation or degeneration. Besides these factors, oestradiol itself plays a major role in co-ordinating follicle development and can be both stimulatory and inhibitory, depending on the amount and duration of exposure (Leung et al., 1978; Hutz et al., 1988). Two days of diethylstilboestrol treatment increases granulosa cell proliferation and causes ovarian weight gain (Goldenberg et al., 1972), while 4 days of treatment leads to degeneration of follicles, reduced viability of cells, reduced steroids in follicular fluid and diminished steroidogenic capability of cells in vitro (Dierschke et al., 1983; Sadrkhanloo et al., 1987). It has been postulated 
Table 1. Numbers of follicles and granulosa cells after 1, 2, 3 or 4 doses of $2 \mathrm{mg}$ diethylstilboestrol/rat

\begin{tabular}{|c|c|c|c|}
\hline \multirow{2}{*}{$\begin{array}{l}\text { Number of doses } \\
\text { of diethylstilboestrol }\end{array}$} & \multicolumn{3}{|c|}{ Follicle size } \\
\hline & Small & Medium & Large \\
\hline & \multicolumn{3}{|c|}{ Number of follicles/ovary } \\
\hline 1 & $120 \pm 24$ & $25 \pm 4^{a}$ & $8 \pm 0 \cdot 8^{c}$ \\
\hline 2 & $145 \pm 72$ & $34 \pm \quad 5^{a}$ & $6 \pm 2^{\circ}$ \\
\hline 3 & $136 \pm 11$ & $69 \pm \quad 9^{b}$ & $5 \pm 1^{\circ}$ \\
\hline 4 & $144 \pm 15$ & $83 \pm 11^{\mathrm{b}}$ & $4 \pm 0 \cdot 4^{d}$ \\
\hline & \multicolumn{3}{|c|}{ Number of granulosa cells/follicle of each size } \\
\hline 1 & $323+31^{3}$ & $3915+160^{\mathrm{b}}$ & $5350+250^{d}$ \\
\hline 2 & $354 \pm 42^{\mathrm{a}}$ & $2960 \pm 204^{\mathrm{b}}$ & $7900 \pm 121^{\circ}$ \\
\hline 3 & $480+42^{b}$ & $1760 \pm 133^{\mathrm{a}}$ & $8150+206^{c}$ \\
\hline 4 & $592 \pm 72^{b}$ & $2100 \pm 224^{a}$ & $6250 \pm 415$ \\
\hline
\end{tabular}

Data are means \pm s.e.m. from 5 experiments, each with pooled ovaries from 10 animals. Significantly different values between rows in each column are denoted by alphabetical letters in superscripts $(\mathrm{a}<\mathrm{b}: P<0.01 ; \mathrm{d}<\mathrm{c}$ : $P<0.05$, compared with values for other doses for each follicle size). Values with the same superscripts are not significantly different.

that oestrogens are initially mitogenic, but then induce the synthesis of a 'regulatory protein' in the follicle (Hutz et al., 1986) which inhibits further growth.

This hypothesis was the basis of the present study, which showed that prolonged diethylstilboestrol treatment inhibited proliferation of granulosa cells from the medium-sized follicles (Fig. 1). In vivo, multiplication rates increase steadily as the follicles grow from small primary follicles to antral follicles. However, Hirshfield (1985) has shown that mitotic index clearly varies under different physiologic conditions. Mitotic indices of small follicles in prepubertal rats are far greater than those of adult animals, suggesting that the rate of early follicular growth is not constant, but is modulated by hormonal cues. Endogenous FSH has been shown to stimulate medium follicles the most (Hirshfield, 1985), but we found that oestrogen stimulated multiplication rates most in the small follicles (Chakravorty et al., 1990). The rise in the rates for the medium follicles at $48 \mathrm{~h}$ could be due to the endogenous FSH surge at $36 \mathrm{~h}$. The similarity in multiplication rates of the small and medium follicles in the present study may have reflected a combined effect of oestrogen on the small follicles and FSH on the medium follicles in the first $48 \mathrm{~h}$ after diethylstilboestrol treatment. With continued treatment, however, there was a decrease in the rates of incorporation, especially in the medium follicles.

The increase observed in the number of medium follicles with increasing diethylstilboestrol treatment (Table 1) seems to contradict the inhibition hypothesis, but careful analysis of the rates of proliferation (Fig. 1) showed that the growth rate of small follicles remained unaffected by prolonged diethylstilboestrol treatment. Small follicles continued to grow and contribute to the total number of medium follicles in the ovary, but, since the activity of the inhibitor was greatest in the medium follicles, the further growth of medium follicles was arrested, leading to fewer large follicles, but an increase in the number of medium-sized follicles. Furthermore, there was a decrease in number of granulosa cells in the medium follicles (Table 1) suggesting that, though there were more medium follicles, these did not have their full complement of granulosa cells because cell proliferation had been inhibited. This finding supports the inhibition hypothesis.

Prolonged diethylstilboestrol treatment also inhibited aromatase activity. Oestrogen production after 1 or 2 injections was lower than normal cycling concentrations (Chakravorty et al., 1990) as little aromatase activity developed without FSH. However, even this low oestrogen synthetic capacity was significantly inhibited with continued diethylstilboestrol treatment. It has been reported that a number of enzymes in the steroidogenic pathway are inhibited by oestrogens (Veldhuis et al., 
1985b). Oestrogens inhibit 3 $\beta$-hydroxysteroid dehydrogenase and also $17 \alpha$-hydroxylase (Munabi et al., 1983). Action of diethylstilboestrol on these enzymes is ruled out in the present study as testosterone was added as substrate for the enzyme aromatase. Therefore, the oestrogen effect seen here could have been a specific inhibition of either the synthesis or the activity of the aromatase enzyme. The direct effect is more likely as the inhibition was present after the FSH surge seen at $36 \mathrm{~h}$ which results from 2 injections of diethylstilboestrol (Chakravorty et al., 1990). This indicated that diethylstilboestrol directly and irreversibly inhibits aromatase so that the enzyme does not respond to endogenous or exogenous FSH. This further proves that diethylstilboestrol was affecting differentiative functions in two possible ways: either by inhibiting aromatase or by reducing its response to FSH, the effect depending on the degree of exposure to the oestrogen. The reduced response to FSH could result from the lack of development of adequate FSH receptors.

Since the granulosa cells are rapidly proliferating, growth stimulators as well as inhibitors may be involved in regulating growth of follicles. Inhibition is necessary in cells from the small and, particularly, the medium follicles (diameters $200-300 \mu \mathrm{m}$ in rats), most of which are prevented from further growth and undergo atresia in each cycle (Hirshfield, 1985). Several peptide factors regulate this dynamic process and most are in the follicular fluid. To investigate the cause of the inhibition seen in the medium follicles, the effects of follicular supernatant from all sizes of follicles on $\left[{ }^{3} \mathrm{H}\right]$ thymidine incorporation were studied. The term 'follicular supernatant' was used to designate fluid collected after gentle rupture of the follicles during isolation of granulosa cells. This fluid constituted not only fluid from the medium and large antral follicles but also extracellular fluid collecting in small and medium preantral follicles. The possibility of contamination with intracellular fluid cannot be ruled out, but we feel this is unlikely, as a viability check of the granulosa cells after isolation and follicle rupture showed that $70-80 \%$ of the cells were intact and viable.

Supernatant from follicles of some sizes showed inhibition depending on the duration of oestrogen treatment and the dose of follicular fluid. Since there was a dose-related inhibition, the inhibitory effects were due to a specific factor in the supernatant fluid. To rule out the effects of steroids, charcoal-treated follicular supernatant was also tested, but charcoal treatment did not remove the inhibitory effects (data not shown), suggesting that the effects could have been due to a peptide factor. Treatment with trypsin abolished the inhibitory effect. Follicular supernatant proteins in doses ranging from 50 to $300 \mu \mathrm{g}$ were tested; doses of $150-300 \mu \mathrm{g}$ were inhibitory, depending on the follicle size and duration of diethylstilboestrol treatment; doses of 50-100 $\mu \mathrm{g}$ lacked inhibitory effects in any treatment group and in any follicle size (data not shown). Nonspecific protein action was ruled out by the demonstration that $100-300 \mu \mathrm{g}$ of BSA had no effect on thymidine incorporation into granulosa cell DNA in culture. The inhibitory characteristics were related to diethylstilboestrol exposure and follicle size: small follicles produced effective concentration of the inhibitor only after 4 injections of diethylstilboestrol, and $300 \mu \mathrm{g}$ of the protein was required to demonstrate the inhibitory effect; but the medium follicles produced more protein sooner (after 3 and 4 injections) and the protein was effective at a lower concentration $(150 \mu \mathrm{g})$, greater inhibition being obtained with $300 \mu \mathrm{g}$ (Fig. 4). Moreover, the follicular supernatant from the large follicles did not have any inhibitory effect even after prolonged diethylstilboestrol exposure. The possibility that the reduced incorporation was due to loss of cell viability due to culture conditions was tested in two ways. Firstly, cells were dispersed at the end of culture and counted by a modification of the method described by Freshney (1987); the recovery was $75-80 \%$ in both control and follicular-fluid-treated cells, with no significant differences in viability between the supernatant-treated and untreated groups. Secondly, recovery and an increase in thymidine incorporation was seen during an additional $48 \mathrm{~h}$ of culture after removal of the media containing follicular supernatant. These findings show that the inhibition was reversible and not associated with cell death. When heated fluid was added to the granulosa cell cultures, the inhibitory properties were still present, suggesting that the peptide had a low molecular weight and was heat stable. 
Failure of charcoal treatment of the follicular supernatant to remove the inhibitory activity, loss of activity upon trypsin treatment and the inability of exogenous steroids to inhibit incorporation further argue against the inhibitory component being a steroid and suggest that it is peptidic in nature. Preliminary analysis using Centricon microconcentrators (Amicon, Danvers, MA, USA) showed that the inhibitory activity in the follicular fluid was associated with a material of $M_{\mathrm{r}}<10000$. A similar ovine follicular fluid inhibitor $M_{\mathrm{r}}<10000$ and insensitive to heat denaturation has been reported to inhibit thymidine incorporation in fibroblasts (Carson et al., 1988). Several peptides have been demonstrated in follicular fluid as well. For example, follicle regulatory protein (FRP, $M_{\mathrm{r}} 12500-15000$ ) isolated from human follicles (diZerega et al., 1982, 1983; Tonetta et al., 1988) specifically inhibits steroidogenesis. Other peptides inhibit binding of FSH to its receptors (Reichert et al., 1984). The protein inhibitor found in this study was produced mainly by granulosa cells of medium follicles and affected only thymidine incorporation and not steroidogenesis (Fig. 6) and is, therefore, unlikely to be FRP.

The effects of oestrogen in co-ordinating follicle development by positive and negative actions reflects an interplay between systemic and local paracrine systems. Many investigators have hypothesized that the timely induction of the aromatase system with concomitant changes in granulosa cell proliferation profiles and intrafollicular steroids are major determinants of (i) selection of the dominant follicle early in the cycle (Richards, 1979; McNatty, 1982) and (ii) the atresia of most of the growing follicles during that cycle. In general, reduction or removal of oestrogen effects by antioestrogens results in a folliculotrophic effect in most model systems, i.e. other follicles in addition to the dominant one are allowed to grow (Hutz, 1989). Therefore, oestrogen from the dominant follicle has been implicated in suppressing the development of other follicles by inducing atresia (Dierschke et al., 1985; Zeleznik et al., 1985; Hutz et al., 1988). The dominant follicle itself is said to escape because it has an elaborate microvasculature delivering more FSH and because it acquires abundant $\mathrm{LH}$ receptors and $\mathrm{LH}$ can increase cAMP concentrations to continue maintaining growth (Zeleznik et al., 1985).

The findings of the present study are in keeping with those in monkeys with exogenous oestrogens. In studies by Koering (1987), prior exposure to high concentrations of exogenous oestradiol reduced the mean percentage of developing antral follicles and increased the number of early atretic follicles; no change was seen in the number of small follicles. We, therefore, propose that the high concentrations of oestrogen produced by the dominant follicle regulate the growth of small and medium follicles via the synthesis of a local factor, which may be peptidic in nature and which inhibits proliferation. The effect seems to be greatest in the medium follicles, which are at a critical stage of development when their fate is decided. It is possible that synthesis of the inhibitory protein is increased as the follicle grows from a small to medium, under the effect of increasing oestradiol concentrations. By inhibiting proliferation, the number of granulosa cells is reduced, thereby further reducing follicular oestrogen production. This effect, with inhibition of aromatase, deprives the follicle of the minimal critical mitogenic concentration of oestrogen needed to maintain growth and the follicle undergoes atresia. However, the relative concentration of the inhibitor is effectively lowered by continued growth of selected medium follicles into large ones, possibly because of dilution in large amounts of antral fluid. Thus, our studies suggest that, in addition to oestrogen reducing gonadotrophic support of follicle growth via negative feedback (Zeleznik et al., 1985), premature increase in oestradiol affects growth of medium follicles by causing the synthesis of local regulatory factors. This speculation would also help to explain the reported detrimental effects of locally administered oestrogens on follicle growth (Dierschke et al., 1983, 1985).

The conclusions drawn from the present study are based on the effects of supernatant fluid collected from follicles showing the presence of a heat-stable, nonsteroidal factor involved in the local regulation of follicle development. The composition of the supernatant follicular fluid and its nature compared with pure follicular fluid is not known. Further biochemical characterization of the fluid and the peptidic factor is currently being done in this laboratory. 
The authors thank V. S. Stopper for valuable technical assistance. This work was supported in part by grant *HD 24488.

\section{References}

Carson, R.S., Robertson, D.M. \& Findlay, J.K. (1988) Ovine follicular fluid inhibits thymidine incorporation by 3 T 3 fibroblasts in vitro. J. Reprod. Fert. 82, $447-455$.

Chakravorty, A., Mahesh, V.B. \& Mills, T.M. (1991) Regulation of follicular development by diethylstilboestrol in ovaries of immature rats. J. Reprod. Fert. 92 , 307-321.

Daniel, S.A.J. \& Armstrong, D.T. (1980) Enhancement of follicle stimulating hormone induced aromatase activity by androgens in cultured rat granulosa cells. Endocrinology 107, 10271033.

Dierschke, D.J., Hutz, R.J. \& Wolf, R.C. (1985) Induced follicular atresia in rhesus monkeys: strength-duration relationships of the oestrogen stimulus. Endocrinology 117, 1397-1403.

Dierschke, D.J., Braw, R.H. \& Tsafriri, A. (1983) Estradiol-17 $\beta$ reduces the number of ovulations in adult rats. Biol. Reprod. 29, 1147-1154.

diZerega, G.S., Goebelsman, V. \& Nakamura, R.M. (1982) Identification of protein(s) secreted by the preovulatory ovary which suppresses the follicle response to gonadotropins. J. clin. Endocr. Metab. 54, 1091-1096.

diZerega, G.S., Marrs, R.P., Roche, P.C., Campeau, J.D. \& Ling, O.R. (1983) Identification of proteins in pooled human follicular fluid which suppresses follicular response to gonadotropins. J. clin. Endocr. Metab. 56, 35-44.

Dorrington, J.H., Chuma, A.V. \& Bendell, J.J. (1988) Transforming growth factor $-\beta$ and follicle stimulating hormone promote rat granulosa cell proliferation. Endocrinology 123, 353 359.

Freshney, R.I. (1987) Maintenance of the culture-cell lines. In Culture of Animal Cells: A Manual of Basic Techniques (2nd edn), pp. 131 133. Alan R. Liss Inc., New York.

Goldenberg, R.L., Vaitukaitis, J.L. \& Ross, G.T. (1972) Oestrogen and follicle stimulating hormone interactions on follicle growth in the rat. Endocrinology 97, 14921498.

Hirshfield, A.N. (1985) Comparison of granulosa cell proliferation in small follicles of hypophysectomized, prepubertal and mature rats. Biol. Reprod. 32, 979 987.

Hirshfield, A.N. \& Schmidt, W.A. (1987) Kinetic aspects of follicular development in the rat. In Regulation of Ovarian and Testicular Function, pp. 211-236. Eds V. B. Mahesh, D. S. Dhindsa, E. Anderson \& S. P. Kalra. Plenum Press, New York.

Hutz, R.J. (1989) Disparate effects of estrogens on in vitro steroidogenesis by mammalian and avian granulosa cells. Biol. Reprod. 40, 709-713.

Hutz, R.J., Dierschke, D.J. \& Wolf, R.C. (1986) Markers of atresia in ovarian follicular components from rhesus monkeys treated with estradiol-17ß. Biol. Reprod. 34, 65-70.

Hutz, R.J., Dierschke, D.J. \& Wolf, R.C. (1988) Induction of atresia of the dominant follicle in rhesus monkeys by the local application of oestradiol-17ß.Am.J. Primatol. 15, 69-77.

Koering, M.J. (1987) Follicle maturation and atresia: morphological correlates. In The Primate Ovary, pp. 3 23. Ed. R. L. Stouffer. Plenum Press, New York.

Leung, P.C.K., Goff, A.K., Kennedy, T.C. \& Armstrong, D.T. (1978) An intraovarian inhibitory action of oestrogen on androgen production in vivo. Biol. Reprod. 19, 641-647.

Lowry, O.H., Rosebrough, H.F., Farr, H.L. \& Randall, R.F. (1951) Protein measurement with the Folin phenol reagent. J. biol. Chem. 143, 257-269.

McNatty, K.P. (1982) Ovarian follicular development from the onset of luteal regression in humans and sheep. In Follicular Maturation and Ovulation, pp. 1-18. Eds R. Roland, E. V. van Hall, S. G. Hillier, K. P. McNatty \& J. Schoemaker. Excerpta Medica, Amsterdam.

Mills, T.M. \& Osteen, K. (1977) 17- $\beta$ oestradiol receptor and progesterone and 20a-pregnen-3-one content of the developing corpus luteum of the rabbit. Endocrinology 101, 1744 1750.

Munabi, A.K., Cassorla, F.G., Pfeiffer, D.G., Albertson, B.D. \& Loriaux, D.L. (1983) The effects of oestradiol and progesterone on rat ovarian 17 -hydroxylase and $3 \beta$-hydroxysteroid dehydrogenase activities. Steroids 41, 95-98.

Parker, C.R., Ellegood, J.O. \& Mahesh, V.B. (1975) Methods for multiple steroid radioimmunoassays. $J$. Steroid Biochem. 6, 1-8.

Reichert, L.E., Jr., Andersen, T.T., Brance, A.A., Fletcher, P.W. \& Sluss, P.M. (1984) FSH binding inhibitors in follicular fluid. In Gonadal Proteins and Peptides and their Biological Significance, pp. 153-160. Eds M. R. Sairam \& L. E. Atkinson. World Scientific Publication, Singapore.

Richards, J.S. (1979) Hormonal control of ovarian follicular development: a 1978 perspective. Recent Prog. Horm. Res. 35, 343-373.

Sadrkhanloo, R., Hofeditz, C. \& Erickson, G.F. (1987) Evidence of widespread atresia in the hypophysectomized estrogen-treated rat. Endocrinology 120, 146-155.

Soto, A.M. \& Sonnenschein, C. (1987) Cell proliferation of estrogen sensitive cells: the case of negative control. Endocr. Rev. 8, 44-52.

Tonetta, S.A., Yanagihara, D.L., DeVinna, R.S. \& diZerega, G.S. (1988) Secretion of follicle regulatory protein by porcine granulosa cells. Biol. Reprod. 38, $1001-1007$.

Veldhuis, J.D., Azimi, P., Garmay, J. \& Juchter, D. (1985b) Bipotential action of oestrogen on progesterone biosynthesis by ovarian cells. I. Relation of oestradiol's inhibitory actions to cholesterol and progestin metabolism in cultured swine granulosa cells. Endocrinology 116, 1818-1825.

Zeleznik, A.J., Hutchison, J.S. \& Schuler, H.M. (1985) Interference with the gonadotrophin-suppressing actions of oestradiol in macaques overrides the selection of a single provulatory follicle. Endocrinology 117, 991-999. 